\title{
RELATIONSHIP BETWEEN UNSAFE ACTION AND CONDITION WITH WORK ACCIDENT AMONG PRODUCTION UNIT WORKERS AT THE JAYA SENTRIKON INDONESIA COMMPANY, PADANG, WEST SUMATRA
}

\author{
Devina Lenggo Putri'), Sumihardi²), Asep Irfan²), I Made Djaja1) \\ ${ }^{1)}$ Department of Environmental Health, Faculty of Public Health, Universitas Indonesia \\ 2)Study Program of Environmental Health, School of Health Polytechnics, \\ Ministry of Health Padang, West Sumatra
}

\begin{abstract}
Background: Work accident is a significant burden to society. Multiple factors contribute to work accident. Previous studies have focused on identifying individual and workplace contributing factors. Unsafe action and unsafe worksite may contribute to injury among workers. This study aimed to determine the relationship between unsafe action and condition with work accident among production unit workers at the Jaya Sentrikon Indonesia Commpany, Padang, West Sumatra.

Subjects and Method: This was a cross sectional study conducted at Jaya Sentrikon Indonesia Commpany, Padang, West Sumatera from September 2016 to Februari 2017. A sample of 50 workers was selected for this study. The dependent variable was work accident. The dependent variables were unsafe action and unsafe condition. The data were collected by a set of questionnaire and observation. The data was analyzed by a multiple logistic regression.

Results: $60 \%$ workers aged $>36$ years old. $100 \%$ workers were male. As many as $62 \%$ workers had experienced work accident. 50\% workers did unsafe action and $64 \%$ had unsafe condition. The risk of work accident increased with unsafe action $(\mathrm{OR}=24.43 ; 95 \% \mathrm{CI}=4.59$ to $130.01 ; \mathrm{p}=0.001)$ and unsafe condition $(\mathrm{OR}=11.26 ; 95 \% \mathrm{CI}=2.88$ to $43.93 ; \mathrm{p}=0.001)$.
\end{abstract}

Conclusion: The risk of work accident increases with unsafe action and unsafe condition.

Keywords: work accident, unsafe action, unsafe condition.

\section{Correspondence:}

Devina Lenggo Putri. Department of Environmental Health, Faculty of Public Health, Universitas Indonesia, Depok, West Java. Email: devinalenggo@gmail.com. Mobile: +6281268435893.

\section{BACKGROUND}

Progress in the industry in Indonesia has opened up jobs that can accommodate the workforce and to increase optimal work productivity, the industry must pay attention to occupational health and safety, especially for workers and society in general (Ministry of Manpower RI, 2003). Occupational health and safety is one aspect of labor protection that is regulated in Law Number 13 of 2003. Although the provisions regarding occupational health and safety have been regulated in such a way, but in practice it is not as expected. Many factors in the field that affect occupational health and safety such as human, environmental and psychological factors that caused work accidents (Sucipto, 2014).

According to Heinrich, in 1953-196 accidents that occurred in various industries were caused by unsafe action (96\%) with the highest percentage due to work position, work equipment, someone's actions and personal protective equipment as well as things originating from humans or workers themselves, Henrich also revealed that unsafe conditions also underlie and cause occupational accidents (Kuswana, 2014).

In addition, study by Nkem et al. (2016) states that there is a significant relationship between unsafe actions or conditions and workplace accidents with a positive corre- 
lation of 0.887 (Nkem et al., 2015).

Data from the International Labor Organization (ILO) in 2013 noted that every year, there were more than 250 million workplace accidents and more than 160 million workers sick due to hazards at work (International Labor Organization, 2013). Supported by data from the International Labor Organization (ILO) in 2015 which states that every day, there are around 6,000 fatal work accidents in the world. In Indonesia, there are accident cases that are experienced every day by 100 thousand workers and $30 \%$ of them occur in the construction section (Social Security Administration Agency, 2015).

The Employment Insurance Agency (BPJS) noted that during 2014, there were 129,911 cases of work accidents in Indonesia, and $34.43 \%$ were caused by unsafe work positions, $32.21 \%$ were caused by workers who did not use safety equipment, $51.13 \%$ due to collisions and $32.25 \%$ is caused by working machinery. In 2015, there were 110.285 cases of work accident in Indonesia and in 2016, there were 105,182 cases of work accidents in Indonesia. For the Padang city, there was an increase in work accident cases in 2016 to 1.535 work accident cases (Social Security Organizing Agency, 2015; Padang City Social Security Organizing Agency, 2016).

One of the industries in Padang that still experiences work accidents every year is PT Jaya Sentrikon Indonesia Padang. In 2011. there were 6 cases of work accidents, in 2012, there were 7 cases of work accidents including 1 person died, in 2013 there were 4 cases of work accidents, in 2014 there were 3 cases of work accidents which caused by grinding machine, electrocuted, affected by broken tires and squeezed by poles and minor injuries due to tools and machines.

Based on a preliminary survey by conducting interviews with the Head of
Personnel at PT Jaya Sentrikon Indonesia, information was obtained that there were 3 cases of work accidents in 2015, and 3 cases of severe work accidents in 2016. From the results of interviews with researchers with 10 workers in the production department of PT Jaya Sentrikon Indonesia Padang found that 8 out of 10 workers ( $80 \%$ ) had experienced work accidents ranging from minor work accidents to severe work accidents includeing wire rope, pinched conveyor, exposed to electric current, exposed to limpack sockets, chains to pinched machines that cause workers to lose their fingers.

From the observations in the field, 4 out of 10 workers in the production department perform unsafe actions such as not using PPE when working, smoking, working while talking and being unsafe to workers because of the unsafe machine layout and 4 workers were working by using inadequate safety shoes. From the results of the description above, the authors was interested in conducting a study to find out the relationship between unsafe action, unsafe condition and work accident at the workers in the production of PT Jaya Sentrikon Indonesia Padang in 2017.

\section{SUBJECTS AND METHOD \\ 1. Study Design \\ This study was a quantitative study with a cross sectional approach, which was a study to find out the differences between unsafe actions, unsafe conditions of workplace accidents, by interviews, observations or data collection at one time (point time approach) to analyze the relationship of unsafe actions, unsafe condition with workplace accidents on PT Jaya Sentrikon Indonesia Padang Tahum 2017 among production division workers.}

\section{Population and Sample}

The population in this study were all workers in the production section that were directly related to the production of concrete piles of 
PT Jaya Sentrikon Indonesia Padang by workers, of whom 10 were respondents as respondents in conducting the initial survey. In this study, authors took all workers of the production of PT Jaya Sentrikon Indonesia Padang in 2017 as a sample in the study of 50 workers. The sampling technique used in this study was total sampling where the number of samples was equal to the population.

The data collected was primary data and secondary data with data processing in the form of editing, coding, entry, and cleaning. Data analysis used univariate analysis and bivariate analysis using Chi-square test with alpha $=0.005$ and 95\% confidence interval and multvariate analysis by using Multivariable Logistic Regression prediction models.

\section{RESULTS}

Table 1. Distribution of Frequency of Occurrence and Type of Accidents in Production Workers of PT Jaya Sentrikon Indonesia Padang in 2017

\begin{tabular}{ccc}
\hline Work Accident & Frequency (f) & Percentage (5) \\
\hline Yes & 31 & $62 \%$ \\
No & 19 & $38 \%$ \\
Total & 50 & 100 \\
\hline Type of Work Accident & Frequency (f) & Percentage (\%) \\
\hline Fell Down & 1 & $3.2 \%$ \\
Hit by Objects & 6 & $19.4 \%$ \\
Slip & 2 & $6.5 \%$ \\
Pinched By Objects & 3 & $9.7 \%$ \\
Crushed or hit by objects & 19 & $61.2 \%$ \\
Total & 31 & $100 \%$ \\
\hline
\end{tabular}

Based on Table 2, it showed that 25 workers (50\%) worked with unsafe actions and 32 workers (64\%) were in unsafe conditions. Types of unsafe actions taken by workers who have work accidents in this study were not using PPE (22.5\%), chatting while working (9.6\%), smoking while working (42\%), carrying excessive loads
Based on the results compiled from 50 workers as the samples, all workers (100\%) were male, all workers (100)\% had a working period of $>2$ years with a work shift from o8.00 - 16.0o WIB, workers aged $<36$ years were 20 people, and workers aged $>36$ years old were 30 people. In addition, there was no meaningful relationship between age and work accident among PT Jaya Sentrikon Indonesia Padang workers in 2017.

Based on Table 1. it shows that more than half $(62 \%)$ who were 31 production workers experienced work accidents. The most types of work accidents experienced by workers of PT Jaya Sentrikon Indonesia Padang in 2017 were crushed or hit by objects by 13 people (61.2\%), and the other was hit by objects by 6 people (19.4\%), pinched by objects by 3 people (9.7\%), slipped by 2 people (6.5\%) and 1 person $(3.2 \%)$ fell while working.
(13\%), not focus while working (9.6\%), working while eating or drinking (3.3\%) and unsafe conditions in this study were PPE that was not suitable (15\%), PPE that was not provided (1.3\%), PPE was not enough (32.5\%), narrow location (1.3\%), machines without safety (13.5\%), unsafe machine layout (36.4\%) (see table 3).

Table 2. Frequency Distribution of Unsafe Action and Unsafe Condition in Production Workers 
of PT Jaya Sentrikon Indonesia Padang in 2017

\begin{tabular}{ccc}
\hline Action & Frequency (f) & Percentage (\%) \\
\hline Not Safe & 25 & $50 \%$ \\
Safe & 25 & $50 \%$ \\
Total & 50 & $100 \%$ \\
\hline Condition & Frequency (f) & Percentage (\%) \\
\hline Not Safe & 32 & $64 \%$ \\
Safe & 18 & $36 \%$ \\
Total & 50 & $100 \%$ \\
\hline
\end{tabular}

Table 3. Frequency Distribution of Unsafe Action and Unsafe Condition Types for Workers in Work Accidents in the Production Section of PT Jaya Sentrikon Indonesia Padang in 2017

\begin{tabular}{|c|c|c|c|c|c|c|}
\hline \multirow[t]{2}{*}{ No } & \multirow[t]{2}{*}{ Actions } & \multicolumn{2}{|c|}{ Workers } & \multirow[t]{2}{*}{ Conditions } & \multicolumn{2}{|r|}{ Workers } \\
\hline & & $\mathbf{F}$ & Percentage & & $\mathbf{F}$ & Percentage \\
\hline 1 & Not using (PPE) & 7 & $22.5 \%$ & PPE is improper to use & 11 & $15 \%$ \\
\hline 2 & Talking while working & 3 & $9.6 \%$ & PPE is not available & 1 & $1.3 \%$ \\
\hline 3 & Smoking while working & 13 & $42 \%$ & PPE is not enough & 24 & $32.5 \%$ \\
\hline 4 & Excessive weight lifting & 4 & $13 \%$ & Narrow location & 1 & $1.3 \%$ \\
\hline 5 & Not focus in working & 3 & $9.6 \%$ & Machine without safety & 10 & $13.5 \%$ \\
\hline 6 & $\begin{array}{l}\text { Eating or drinking } \\
\text { while working }\end{array}$ & 1 & $3 \cdot 3 \%$ & $\begin{array}{l}\text { Machine layout is not } \\
\text { safe }\end{array}$ & 27 & $36.4 \%$ \\
\hline Tota & & 31 & $100 \%$ & Total & 31 & $100 \%$ \\
\hline
\end{tabular}

Based on Table 4, it showed that there was a significant relationship between the unsafe action variable (unsafe action) with the occurrence of work accidents among workers of PT Jaya Sentrikon Indonesia Padang in 2017 with a p-value of 0.001 $(<0.05)$ and the value of $\mathrm{OR}=24.5$ can be interpreted that workers who take unsafe actions (unsafe actions) have 24 times greater risk of experiencing work accidents than workers who did not take unsafe actions. It also showed that unsafe conditions have a significant relationship with the incidence of work accidents in workers of PT Jaya Sentrikon Indonesia Padang in 2017 with $\mathrm{p}=0.001(<0.05)$ and the value of $\mathrm{OR}=$ 11.3, it can be interpreted that workers who were in an unsafe environment have a risk to experience work accidents by 11.3 times greater compared to workers who were in a safe environment.

Table 4. The Relationship between Unsafe Action and Unsafe Condition with Work Accidents in Production Workers of PT Jaya Sentrikon Indonesia Padang in 2017

\begin{tabular}{ccccccccc}
\hline \multirow{2}{*}{ Action } & \multicolumn{4}{c}{ York Accident } & \multicolumn{2}{c}{ Total } & \multirow{2}{*}{ OR (95\% CI) } & \multirow{2}{*}{$\mathbf{p}$} \\
\cline { 2 - 8 } & F & \% & F & \% & F & \% & & \\
\hline Not Safe & 23 & 92 & 2 & 8 & 25 & 100 & 24.44 & \\
Aman & 8 & 32 & 17 & 68 & 25 & 100 & $(4.59-130.01)$ & 0.001 \\
Total & 31 & 62 & 19 & 38 & 50 & 100 & & \\
\hline
\end{tabular}

Condition

Work Accident

Total

OR 95\% CI

$\mathbf{p}$ 


\begin{tabular}{ccccccccc} 
& \multicolumn{2}{c}{ Yes } & No & & & & \\
& F & \% & F & \% & F & \% & & \\
\hline Not Safe & 26 & 81 & 6 & 19 & 32 & 100 & 11.27 & \\
Aman & 5 & 27.8 & 13 & 72.2 & 18 & 100 & $(2.89-43.93)$ & 0.001 \\
Total & 31 & 62 & 19 & 38 & 50 & 100 & & \\
\hline
\end{tabular}

In this study, it was found that the unsafe action and unsafe condition have a relationship with the incidence of work accidents on workers in the production of PT
Jaya Sentrikon Indonesia Padang in 2017 as shown in table 5. The Exp.B value of the unsafe action variable was $17.2(95 \% \mathrm{CI}=2.93$ $-101.34)$.

Table 5. Multivariate Analysis Results of Unsafe Action Variables, Unsafe Conditions with Work Accidents in Production Workers of PT Jaya Sentrikon Indonesia in 2017 Logit Y Work Accident $=-3.0+2,846$ unsafe action, 1.952 unsafe condition $+\mathrm{e}$

\begin{tabular}{ccccc}
\hline Variables & B & OR (Exp.B) & 95\% CI & P \\
\hline Unsafe Action & 1.952 & 7.044 & $1.41-35.32$ & 0.018 \\
Unsafe Condition & 2.846 & 17.226 & $2.91-101.34$ & 0.002 \\
Constant & -3.020 & 0.049 & & 0.001 \\
\hline
\end{tabular}

\section{DISCUSSIONS}

The results of this study indicated that more than half of the workers have experienced work accidents. Study by Winarto et al. (2016) of oil and gas seismic survey workers at PT X West Papua, stated that half of the sample (50\%) had a work accident. In addition, a study conducted by Lambogia (2018) of workers at PT Tropica Cocoprima stated that more than half (50.7\%) of workers had a work accident. The results of this study were also supported by Khairani in 2015 on the part of production workers who stated that the majority of workers had work accidents (71.7\%) (Khairani, 2015; Winarto et al., 2016; Lombogia et al., 2018).

The types of work accidents in this study were in line with Khairani (2015) which showed that the types of work accidents that often occur were contact with hazardous materials, pounding or being exposed to objects, slipping, falling on objects, pinched by objects, falling, exposed to electric current and burns (Khairani, 2015).

In addition, authors argued that the attitude of workers who did not pay attention to work safety such as not using PPE, in a hurry and not careful when working was also a cause of work accidents, efforts that can be done was to uphold work discipline towards the use of PPE at each workers, raising workers' awareness and concern about work health and safety through training, continuous supervision and morning and evening apples conducted every day to remind workers to work carefully and pay attention to work safety. This was in line with the theory of Suma'mur (2013) which stated that the prevention of work accidents can be done by enforcing discipline and continuous supervision (Suma'ur, 2013).

The results of this study indicated that respondents who experienced work accidents were more than respondents who did unsafe actions (92\%) compared to respondents who did safe actions (32\%) in the last two years. Unsafe actions in this study were in line with Rudyarti (2017) which stated that the use of PPE determined the incidence of workplace accidents, workers who use PPE can avoid accidents at work than workers who did not use PPE (Rudyarti, 2017).

The results of this study also showed that respondents who had experienced work 
accidents were more than respondents in unsafe conditions (unsafe conditions) compared to respondents who were in safe conditions in the last two years. Unsafe conditions that can cause accidents came from risky environments such as unsafe machine layout, poor PPE, improper PPE.

The results of this study were similar with other studies that there was a relationnship between unsafe actions and unsafe conditions with the occurrence of workplace accidents, and several supportive analysis stated that unsafe actions and unsafe conditions was a factor causing work accidents. As stated by Lilian (2017) in the analysis of factors affecting work accidents in the operation of container cranes stated that the direct cause of an accident was the unsafe action of the operator of the crane operator and unsafe conditions in the working area, where the unsafe condition that was from the conditions of the tool was the container crane or the condition of the ship when loading and unloading, whereas the unsafe action came from the action of the container crane operator itself which resulted in an accident. Winarto et al. (2016) also suggested that an unsafe work environment was at risk of causing workplace accidents and there was a signifycant relationship between unsafe environment and workplace accidents at the PT X drilling unit and unsafe environment at risk of causing workplace accidents by 7,467 times higher compared to a safe environment (Winarto et al., 2016).

In this study, workers who did unsafe actions have higher risk of work accidents compared to workers who performed safe actions. This was in line with the case study conducted by Winarto et al. (2016) which stated that the results of multivariate analysis showed the significance of the action with the accident where $p$ value was $0.0001(<0.005)$ with OR/Exp. (B) 11.914 which mean workers who commit unsafe actions have a risk of occurrence of work accidents by 11.914 times higher compared to workers who take actions safely (Winarto et al., 2016). In line with Primadianto et al. (2018) which stated that unsafe action (unsafe action) was a dominant factor in influencing workplace accidents with the value of Exp. $B=1.170$ (Primadianto et al., 2018).

This was in line with the theory of work accidents which stated that the factor of unsafe action and unsafe conditions was one of the dominant factors that cause work accidents, as in the Domino theory which stated that unsafe behavior was in the midst of dominoes others, if people want to prevent work accidents, the factors of unsafe actions and unsafe conditions must be eliminated (Sucipto, 2014). This result was also in accordance with the theory of Loss Causation Model that was put forward by Frank, which stated that unsafe actions and unsafe conditions were the direct causes of work accidents, where there were 2 things that cause unsafe conditions which were improper workplaces and hazardous equipment conditions (Frank, 1986).

According to the researchers, this can occur because of the lack of awareness of each worker of the importance of working safely in order to minimize the occurrence of work accidents. Efforts that can be made bearing in mind the behavioral factors difficult to intervene were increasing supervision of workers, increasing the insurance provided to workers who violate SOPs, providing safety work training to workers, and always instilling a culture of safety in working evenly in every part of the work. For example, by holding a safety meeting every day, distributing PPE that was still feasible and fulfill the requirements for use to all workers, and implementing a $5 \mathrm{~s}$ system for spatial planning in the production division of PT Jaya Sentrikon Indonesia Padang in 2017. This was in line with several other studies which 
also suggested efforts to prevent unsafe actions and unsafe conditions or to increase safe behaviors and actions by making SOPs about safe behavior and its implementation continuously, conducting OHS training, evaluating and monitoring worker behavior, implementing Behavior-Based Safety programs, refraining from haste in carrying out tasks, increasing worker participation to improve work safety and distribution of highquality PPE (Pratama, 2015; Mousavipour et al., 2016; Istih et al., 2017; Sirait and Paskarini, 2017).

The results of this research were not in line with research conducted by Lombogia, in 2018 at PT Trpoica Cocopirma which stated that there was no relationship between unsafe worker behavior and work accident with a $\mathrm{p}=1$.00. Similar research conducted by Wiyonom et al. (2017) stated that there was no significant relationship between unsafe actions with workplace accidents at nurses with $\mathrm{p}=0.231$. Research conducted by Kawatu et al. (2018) showed that there was no relationship between unsafe action and work accidents with the $\mathrm{p}=1.000$ (Bagas et al., 2014; Istih et al., 2017; Lombogia et al., 2018).

In several studies, age was one of the factors that can cause workplace accidents, where age has a significant relationship with workplace accidents ( $\mathrm{p}<0.05)$, older workers were assumed to be more vulnerable to work accidents than younger workers (Afini et al., 2012; Aryantiningsih and Husmaryuli, 2017). However, this study did not justify the theory and stated that there was no relationship between age and work accident. According to researchers, this was because older workers were more $d$ dominant than younger workers, and based on field observations conducted by researchers, it showed that older and younger workers have no difference in how they work. The results of this study were in line with research conducted by Dornaria in Community Health which stated that there was no meaningful relationship between age and work accident (Pinggian et al., 2018).

The conclusion of this study was that more than half (62\%) of workers had work accidents with the largest type of work accident being crushed or exposed to objects (61.2\%). Half of workers who experienced work accidents (50\%) act unsafe and more than half (61.2\%) of workers were in unsafe conditions.

There was a significant relationship between unsafe actions and unsafe conditions with work accident incidents in the workers of PT Jaya Sentrikon Indonesia Padang in 2017 and workers who commit unsafe actions have risk of work accident by 17 times higher than workers who take safe action. Suggestions for PT Jaya Sentrikon Indonesia Padang were to be more strict with no smoking regulations, provide a barrier between working tools, always maintain the neatness of the work environment, remind housekeeping inspections with the application of the $5 \mathrm{~s}$ system, and it is expected that leaders and companies complete health and safety adequacy, one of them is a good personal protective equipment that is suitable for use.

Workers who work in the production division of PT Jaya Sentrikon Indonesia Padang are expected to apply and comply with applicable regulations such as not smoking at work, using complete PPE during work and reminding colleagues when there are unsafe actions or unsafe conditions when work. Further researchers are expected to be able to examine the monitoring variables and other variables that can cause workplace accidents.

\footnotetext{
REFERENCES

Afini PN, Koesyanto H, Budiono Ir (2012). Faktor Penyebab Kecelakaan Kerja Di Unit Instalasi Pabrik Gula (Factors Causing Work Accidents in Sugar Plant
} 
Installation Units), Unnes Journal of Public Health, 3(1): 1-10.

Aryantiningsih DS, Husmaryuli D (2017). Kejadian Kecelakaan Kerja Pekerja Aspal Mixing Plant (Amp) \& Batching Plant Di Pt. Lwp Pekanbaru Tahun 2015 (Occupational Accidents Among Asphalt Mixing Plant (Amp) Workers \& Batching Plant Workers In Pt. Pekanbaru Lwp in 2015), Jurnal Kesehatan Masyarakat Andalas, 10(2): 145. doi: 10.24893/jkma.10.2.145-150.2016.

Badan Penyelenggara Jaminan Sosial (2015) Angka Kasus Kecelakaan Kerja Menurun (The number of work accident cases has decreased). Available at: https://www.bpjsketenagakerjaan.go.id/berita/2943/Angka-Kasus-KecelakaanKerja-Menurun.html

Badan Penyelenggara Jaminan Sosial Kota Padang (2016) Angka Kecelakaan Kerja (Work Accident Rate). Padang.

Bagas UH, Kawatu PA, Joseph WB (2014). Hubungan Antara Tindakan Tidak Aman Dengan Kecelakaan Kerja Pada Tenaga Bongkar Muat di PT PElabuhan Indonesia IV (Persero) Cabang Bitung (The Relationship Between Unsafe Actions and Work Accidents in Unloading Personnel at PT. Pelabuhan Indonesia IV (Persero) Bitung Branch), Jurnal Kesmas, 7(4).

Bird E, Frank J (1986). Practical Loss Control Leadership. Georgia: Devision of International Loss Control Institute.

International Labour Organization (2013) Keselamatan dan Kesehatan Kerja Keselamatan dan Kesehatan Sarana untuk Produktivitas (Work Safety and Health Safety and Health Facilities for Productivity).

Istih SMP, Wiyono J, Candrawati E (2017). "Hubungan Unsafe Action Dengan Kecelakaan Kerja Pada Perawat Di Rumah Sakit Panti Waluya Malang,"
(The Relationship between Unsafe Action and Work Accident in Nurses at Panti Waluya Hospital Malang) Nursing News, 2(2): 337-348. Available at: https://publikasi.unitri.ac.id/index.php/fikes/article/download/478/396. Kemnaker RI (2003) Undang-Undang Republik Indoneia No.13 Tahun 2003 Tentang Ketengakerjaan (Republic of Indonesia Law No.13 of 2003 concerning Manpower), 1-18.

Khairani A (2015). Faktor-Faktor Yang Berhubungan Dengan Kecelakaan Kerja Pada Pekerja Bagian Produksi PT JAya Sentrikon Indonesia Padang Tahun 2015 (Factors Related to Work Accidents in Production Workers of PT JAya Sentrikon Indonesia Padang in 2015.). Univeristas Andalas.

Kuswana W (2014). Ergonomi dan K3 Kesehatan Keselamatan Kerja (Ergonomics and K3 Work Health Safety). Bandung: PT. Remaja Rusdakarya.

Lombogia O, Kawatu PAT, Sumampouw OJ (2018). Hubungan Antara Perilaku Pekerja Yang Tidak Aman Dengan Kecelakaan Kerja Di PT. Tropica Cocoprima Desa Lelema Kabupaten Minahasa Selatan (Relationship Between Unsafe Workers' Behavior and Work Accidents at PT. Tropica Cocoprima, Lelema Village, South Minahasa Regency), Jurnal Kesmas, 7(5): 1-7.

Mousavipour S, Safary VA, Mirzaei R (2016). A Study of the Unsafe Actions of Staff in the Maintenance and Overhaul Unit at a Petrochemical Complex and the Presentation of Control Strategies, Biotechnology and Health Sciences, 3(1): 1-6. doi: 10.17795/bhs-32561.

Nkem AN, Hassim MH, Kidam K (2015). Relationship between unsafe acts/condition and accidents in construction company in Nigeria, Jurnal Teknologi, 75(6): 73-77. 
Pinggian D, Doda VD, Rattu AJM (2018). Faktor-Faktor yang Berhubungan Dengan Kecelakaan Kerja Pada Buruh Angkut Sampah Di Kota Manado (Factors Related to Work Accidents in Garbage Transport Workers in Manado City), 17-25. Retrieved from http://www.ejournalhealth.com/index.php/CH/article/viewFile/14/14.

Pratama AK (2015). Hubungan Karakteristik Pekerja Dengan Unsafe Action Pada Tenaga Kerja Bongkar Muat Di Pt. Terminal Petikemas Surabaya (Relationship between Worker's Characteristics and Unsafe Action in Unloading Workers at PT. Surabaya Container Terminal), The Indonesian Journal of Occupational Safety and Health, 4(1): 64. doi: 10.20473/ijosh.v4i1.2015.6473 .

Primadianto D, Putri SK, Alifen R S (2018). Pengaruh Tindakan Tidak Aman (Unsafe Act) Dan Kondisi Tidak Aman (Unsafe Condition) Terhadap Kecelakaan Kerja Kontruksi (Effect of Unsafe Actions and Unsafe Conditions on Construction Work Accidents), 7(1): 77-84.

Rudyarti E (2017). Hubungan Pengetahuan Keselamatan Dan Kesehatan Kerja Dan Sikap Penggunaan Alat Pelindung Diri Dengan Kejadian Kecelakaan Kerja Pada Pengrajin Pisau Batik Di Pt. X (Relationship between Work Safety and Health Knowledge and Attitude of Use of Personal Protective Equipment with
Work Accidents in Batik Knife Craftsmen in Pt. X), Jurnal Kesehatan Masyarakat, 2(1): 13. doi: No.ISSN online : 2541-5727.

Sirait FA, Paskarini I (2017). Analisis Perilaku Aman Pada Pekerja Konstruksi Dengan Pendekatan Behavior-Based Safety (Studi Di Workshop Pt. X Jawa Barat) (Analysis of Safe Behavior in Construction Workers with the Behavior-Based Safety Approach (Study in PT. X West Java Workshop)), The Indonesian Journal of Occupational Safety and Health, 5(1): 91. doi: 10.20473/ijosh.v5i1.2016.91-100.

Sucipto (2014). Kesehatan dan Keselamatan Kerja (Work Health and Safety). Jakarta: PT. Pustaka Binaman.

Suma'ur (2013). Higene Perusahaan dan Keselamatan Kerja (Company Hygiene and Work Safety). Jakarta: Gunung Agung.

Winarto S, Denny H M, Kurniawan B (2016). Studi Kasus Kecelakaan Kerja pada Pekerja Pengeboran Migas Seismic Survey PT. X di Papua Barat (Case Study of Work Accidents in Oil and Gas Seismic Survey Drilling Workers of PT. $\mathrm{X}$ in West Papua), Jurnal Promosi Kesehatan Indonesia, 11(1): 51. doi: 10.14710/jpki.11.1.51-65. 